\title{
Analysis Level of Utilization Information and Communication Technology with The Competency Level of Extension Workers
}

\author{
Veronice \\ \# Program study of Agricultural Management, Payakumbuh Agricultural Polytechnics, West Sumatera, Indonesia \\ E-mail:veronice0708@gmail.com
}

\begin{abstract}
Extension placed man as the subject of development and human capital to develop into independent and empowered (dignity) in adapting to the environment, thus being able to improve the quality of life for themselves, their families and communities. It is therefore necessary professional competence standard extension clear and effective controls in carrying counseling profession domination supported by Information and Communication Technology (ICT). This research aimed to analyze the relationship between the level of competency with the level of ICT use by the extension workers. The study was designed as a descriptive survey research correlational, which was observed by quantitative analysis approach that is supported by descriptive and inferential statistic analysis. The study was conducted in Bogor Regency, West Java Province. Based on this research can be concluded level of ICT utilization in the range of aspects related resources are very real to the competence of extension on the capability of understanding the potential of the region, entrepreneurial ability and the ability of the system guides the network, while the variation of the material aspects of counseling and a variety of related information is very real with all levels of competence extension.
\end{abstract}

Keywords - competence, extension workers, information and communication technology

\section{INTRODUCTION}

Extension is essentially the professional activities of education services dignified development, namely the respect the community humanism [1] [2]. The main focus of education is the development of human capital as part of a social system. Extension efforts are convergent development community structure, dialogue, democratic, and participatory, so that people in Indonesia who had colonized the old, apathetic and dependent interference by other parties (dependent), then shifted subsistence society (independent) developed into an independent society ( interdependent). Such developments are in line with the concept [3] on the development of human behavior. Extension placed man as the subject of development and human capital to develop into independent and empowered (dignity) in adapting to the environment, thus being able to improve the quality of life for themselves, their families and communities. It is therefore necessary professional competence standard extension is supported by clear and effective control in carrying counseling profession.

Extension workers weakness not only in the aspect of quantity, but also quality is quite alarming. The results of research related to the extension workers of competence [4],[5],[6] showed weak agricultural extension workers competence. The low quality of extension workers is also confirmed by [9] that the extension ideally it should also be able to improvise professionals who are responsible for the situation and field conditions encountered, but professional personnel such currently available is not enough. These conditions indicate the need for all parties to examine how to improve quality.

In line with the implementation of agricultural extension workers paradigm changes and demands of global change, the speed and accuracy of delivery of information technology and alternative and highly effective solutions need carrying. since the last two decades in many developed countries and even developing countries began to pay great attention to the use of information technology and communication (ICT) for showing agricultural extension. ICT use here is also not free from an increase in the quality of farmers and agricultural resources, advances in information technology and communication and also consideration of the effectiveness and efficiency of the dissemination of information, one of the solutions offered in order to address the issue of transfer of technology and knowledge [6].

Science and technology is developing rapidly with the demands of the changing times. ICT developments, especially since the advent of internet technology has led to major changes in society. Information technology products 
are relatively cheap and affordable facilitate access to information beyond national borders and cultural boundaries. This condition has penetrated to all levels of human life, including farmers in the countryside. Now some farmers are accustomed to access information through newspapers, magazines, radio, television, internet, mobile phone or other media. Therefore, the instructor becomes an important role as a facilitator in developing the potential of farmers. As a consequence extension is required to adjust to the changes and demands of the growing community [8].

Based on the current situation and the condition of the extension, the chosen Bogor District as study sites because this area is an area with a variety of ICT usage and fairly high level of accessibility to resources, the instructor been exposed to ICT, network connections are quite extensive, and in Bogor there various units of agricultural research, universities and centers of information. Thus there are various options for agricultural extension in the use of ICT.

\section{RESEARCH METHODS}

The study was designed as a descriptive survey research correlational, which was observed by quantitative analysis approach that is supported by descriptive and inferential statistical analysis. The study was conducted in Bogor Regency, West Java Province by considering that the Bogor district is an area with variations in the use of ICT and a fairly high level of accessibility to resources, extension workers have been exposed to ICT, network connections are quite extensive, and in the Bogor area of research there are various work units agriculture, universities and information centers .

The study was conducted over two months, in March and April 2013 from start test and then proceed with the implementation of the research. The population is agricultural extension workers PNS and THL - TBPP or known as agricultural extension contract in Bogor District of West Java Province. Sampling technique in this study performed using Slovin formula, in order to obtain a total sample of 117 respondents .

The data collected in this study consisted of primary data and secondary data. Primary data is taken from the main variables studied in the form of extension characteristics, environmental factors, motivational counselor to ICT, through the respondent obtained directly by using the instrument in the form of a questionnaire .

Secondary data were collected with regard to the general state, supporting data regarding actual or potential geographic conditions that can be obtained from the parties or related institutions such as the BKP5K, BPS Bogor district or other agencies

\section{RESULTS AND DISCUSSION}

Competency level civil servants extension workers and THL-TBPP an extension ability levels are based on the knowledge, skills, and supported by his attitude in carrying out the task of extension in empowering farmers. Competency level civil servants extension workers and THL-TBPP on the level of ICT use classified in the high category. Distribution of the average scores and the coefficient of $\mathrm{t}$ test competency level civil servants and THL-TBPP presented in Table 1.

TABLE I

DISTRIBUTION OF THE AVERAGE SCORES AND THE COEFFICIENT OF T-TEST BETWEEN THE LEVEL OF COMPETENCE OF CIVIL SERVANTS EXTENSION WORKERS AND THL-TBPP

\begin{tabular}{|c|c|c|c|}
\hline \multirow{2}{*}{$\begin{array}{l}\text { Competency Level } \\
\text { Extension workers }\end{array}$} & \multicolumn{2}{|c|}{ Score means ${ }^{1}$} & \multirow{2}{*}{$\begin{array}{c}\text { The } \\
\text { coefficient } \\
\text { value t-test }\end{array}$} \\
\hline & $\begin{array}{c}\text { Civil } \\
\text { servants }\end{array}$ & $\begin{array}{l}\text { THL- } \\
\text { TBPP }\end{array}$ & \\
\hline $\begin{array}{l}\text { Competence } \\
\text { understanding of the } \\
\text { potential of the } \\
\text { region }\end{array}$ & 3.18 & 3.13 & 0.376 \\
\hline $\begin{array}{l}\text { Communication } \\
\text { skills of inovation }\end{array}$ & 3.10 & 3.11 & 0.072 \\
\hline $\begin{array}{l}\text { Learning } \\
\text { Management } \\
\text { capabilities }\end{array}$ & 3.06 & 3.05 & 0.095 \\
\hline $\begin{array}{l}\text { Renewal } \\
\text { Management } \\
\text { Capabilities }\end{array}$ & 3.18 & 3.05 & 0.290 \\
\hline $\begin{array}{l}\text { Training } \\
\text { Management } \\
\text { Capabilities }\end{array}$ & 2.97 & 2.97 & 0.996 \\
\hline $\begin{array}{l}\text { Enterpreneurial } \\
\text { Capabilities }\end{array}$ & 3.02 & 2.95 & 1.142 \\
\hline $\begin{array}{l}\text { The ability of the } \\
\text { Network System } \\
\text { Guides }\end{array}$ & 3.09 & 3.09 & 0.115 \\
\hline
\end{tabular}

The results of t-test showed no significant differences in civil servants extension worker and THL-TBPP the competence level extension workers. Research hypothesis which states "there are real differences between the level of competence of civil servants and THL-TBPP in the use of ICT is rejected. Ability level civil servants extension workers and THL-TBPP in understanding the potential of the region based on the average score is in the high category in the amount of 3.18 and 3.13. This proves that the extension workers is able to understand the potential of natural resources, able to solve problems and find solutions farmers through training activities and visits, meetings and discussions with officials and members of farmer groups.

Ability level civil servants extension workers and THLTBPP in managing communications innovations classified in the high category, \$3.10 and 3.11. Extension has been able to find information innovation through various resources, understanding the necessary innovation, as well as communicate with a language that is easily understood and carried out through dialogue. This activity is a form of trial or demonstration plots in accordance with the technology specific target areas of each extension. Research results [5] showed that the extension of competence significantly affect the performance of extension (information management and leadership).

Furthermore, the level of ability of civil servants extension workers and THL-TBPP in managing the learning based on the average scores relatively high at 3:06 and 3.05. Extension has been able to take advantage of instructional media and facilitate interaction between farmers learn. This 
is in line expressed by Mardikanto (2010) that the extension contained a change, attitudes and skills so that they know, willing and able to manage their farm in order to achieve the welfare of the family [7].

Ability level civil servants and THL-TBPP in managing renewal based on the average score is in the high category in the amount of 3.18 and 3.05. This shows the extension has been able to raise the motivation of farmers to apply innovation and solve the problems encountered with regard to innovation. Ability level civil servants and THL-TBPP in managing the training is based on the average score is in the high category with the same average value that is equal to 2.97. This indicates that the instructor has the ability to manage the training or courses farmer from the planning phase, implementation, evaluation and its follow-up. Ability level civil servants and THL-TBPP in developing entrepreneurship based on the average score is in the high category is equal to 3.02 and 2.95. This indicates that the extension has been able to encourage farmers to develop a bold attitude in taking risks, opportunities or opportunities in trying farmer. Ability level civil servants extension workers and THL-TBPP in guiding the network system including high category with the same average value that is equal to 3.09 . This suggests that the extension has been able to facilitate the farmers with research institutes or universities as well as partnerships with the business community, facilitating agricultural products and market prices

Another fact found that the average scores for the results look more dominant civil servants at the level of competence extension on competence aspect of understanding the potential of the area and renewal management capabilities with the same average value that is equal to 3.18 . This proves that the civil servants have been able to understand the potential of natural resources, able to solve problems and find solutions farmers through training activities and visits, meetings and discussions with officials and members of farmer groups and has been able to raise the motivation of farmers to apply innovation and solve the problems facing the related to innovation.

The results of t-test showed no significant differences in civil servants and THL-TBPP the competence level extension. Research hypothesis which states "there are real differences between the level of competence of civil servants and THL-TBPP in the use of ICT is rejected.

\section{A. Relationship the level of utilization of ICT with competency level extension workers}

Competency level civil servants extension workers and THL-TBPP an extension ability levels are based on the knowledge, skills, and supported by his attitude in carrying out the task of extension in empowering farmers. Competency level civil servants and THL-TBPP on the level of ICT use classified in the high category.

Furthermore, analysis of the relationship with the extension workers competency level of ICT utilization rate is obtained that level of ICT utilization seen from the indicator range of information sources, variations extension materials, the range of information and quality of knowledge sharing.

The results showed that the range is very real resources positively associated with the ability of understanding the potential of the region, to develop entrepreneurial abilities and capabilities of network system guides. This proves that the increasingly wide range of resources, the extension is proportional to the extension's ability to understand the potential of natural resources, farmers understand the problems and find solutions, also explained that the range of resources able to develop a bold stance in seeking opportunities, take risks and to facilitate partnership with others, especially universities, research institutions and the business world.

Variations extension materials and a variety of information related to the very real positive with all aspects of the competency levels of extension that includes the capability of understanding the potential of the region, the communication capability of innovation capability of learning management, renewal management capabilities, the ability of management training, develop entrepreneurial abilities and capabilities of network system guides. This proves that the variation of extension materials and a range of information is directly proportional to all levels of competence extension. The more material that can be accessed counseling and type of information conveyed by the instructor through the use of ICT, the higher the level of competence, especially in the understanding of potential areas of competence, innovation communication skills, and the ability to guide the network system.

Research hypothesis which states that "there is a real connection between the level of ICT use by extension acceptable level of competence," ie in the range of aspects related resources are very real, especially with the capability of understanding the potential of the region, entrepreneurial ability, and the ability to guide the network system, also aspects of material variations counseling and a variety of related information is very real with all levels of competence extension. This is in line with the opinion of Marius et al. (2007) which states that the extension competent in preparing, evaluating, and developing more education have a significant impact for farmers rather than just to have competence in communication and social interaction.

\section{CONCLUSIONS}

Level of ICT utilization in the range of aspects related resources are very real to the competence of extension on the capability of understanding the potential of the region, entrepreneurial ability and the ability of the system guides the network, while the variation of the material aspects of counseling and a variety of related information is very real with all levels of competence extension.

\section{ACKNOWLEDGMENT}

The authors acknowledge with gratitude the support given by the Directorate general of higher education for research (BPPS DIKTI)

\section{REFERENCES}

[1] Covey, Stephen R. 1993. The 7 Habits of High Effective People (Tujuh Kebiasaan Manusia yang Sangat Efektif). Cet-3. Alih Bahasa Budijanto. 1997. Jakarta : Bina Aksara Rupa

[2] Sumardjo. 2006. " Kompetensi Penyuluh." Makalah disampaikan pada Pertemuan KPPN dengan Departemen Pertanian di Batam pada April 2006. Batam.

[3] Chury, J.A, Mlozi, R.S.M, Tumbo, D.S, Casmir,R. 2012. Understanding Farmers Information Communication Strategies for 
Managing Climate Risks in Rural Semi-Arid Areas, Tanzania. International Journal of Information and Communication Technology Research Vol. 2 No.11, November 2012. pp. 838-845.

[4] Marius, J.A., Sumardjo, Margono Slamet, Pang S.Asngari. 2007. "Pengaruh Faktor Internal dan Eksternal Penyuluh terhadap Kompetensi Penyuluh di Provinsi Nusa Tenggara Barat.”Jurnal Penyuluhan, Vol 3 No 2. September 2007, hal 78-89.

[5] Mulyadi, T.R. 2009. Faktor-faktor yang mempengaruhi kinerja penyuluh pertanian dan dampaknya pada perilaku petani padi di Jawa Barat. Disertasi. Sekolah Pascasarjana IPB. Bogor. [6] Nuryanto, B.G. 2008. Kompetensi Penyuluh dalam Pembangunan Pertanian di Provinsi Jawa Barat. Disertasi. Sekolah Pascasarjana IPB. Bogor.
[6] Nuryanto, B.G. 2008. Kompetensi Penyuluh dalam Pembangunan Pertanian di Provinsi Jawa Barat. Disertasi. Sekolah Pascasarjana IPB. Bogor.

[7] Mardikanto,T. 2010. Penyuluhan Pembangunan Pertanian. Surakarta (ID): Sebelas Maret University Press.

[8] Slamet .2008." Menuju Penyuluh Profesional.” Komunikasi Pribadi. Program Studi Ilmu Penyuluhan Pembangunan. Sekolah Pasca Sarjana Bogor.Bogor.IPB Press

[9] Margono,T, Shigeo, Sugimoto. 2011. Understanding the Gap Issue on Dissemination of Agricultural Information for Extension Workers in Indonesia: A Framework Solution. International Journal of Basic \& Applied Sciences IJBAS-IJENS, Vol. 11 No. 02 April 2011, pp. 98-105. 